\title{
The relation between self-regulated learning, academic performance of graduate student
}

\author{
Amalia Madihie ${ }^{1}$, Zarifah Mos $^{2}$ \\ ${ }^{12}$ Universiti Malaysia Sarawak \\ *)Corresponding author, ఏ-mail: mamalia@unimas.my
}

\begin{abstract}
The purpose of this study is to find an independent learning relationship with the academic performance of graduate students. Eighty graduate students from the Science and HumanResource Learning Program at the Cognitive Faculty of Human Science and Development were randomly selected. Questionnaire used was adopted from Pintrich, 1991, motivated strategies for Learning Questionnaire. The variables studied in this study are motivation and learning strategies. Academic performance is measured as the dependent variable which is the current CGPA graduate student. The research findings show that there is no relationship between motivation and learning strategies with academic achievement.
\end{abstract}

Keywords: self-regulated, motivation, learning strategies, academic performance, graduate students

How to Cite: Madihie, A., Mos, Z. (2018). The relation between self-regulated learning, academic performance of graduate student. Couns-Edu: International Journal of Counseling and Education, 3(2): pp. 63-68. DOI: https://doi.org/10.23916/002018039020

This is an open access article distributed under the Creative Commons Attribution License, which permits unrestricted use, distribution, and reproduction in any medium, provided the original work is properly cited. (C2017 by author and Indonesian Counselor Association (IKI).

\section{Introduction}

Every year, the numbers of graduate students in educational institutions are rise slightly. These graduate students really do play an important role in country development either in educational, economic growth or other sector. In addition, worker with high qualifications in skills and knowledge are most needed where it can contribute towards development and improvement of local or international organizations. Towards this, self-regulated learning is very essential to the graduate students where they would be able to perform well in academic, practical and become an excellent student. Self-regulated learning should be apply and embedded inside the students as long as they learn and be a student in educational institutions. According to Cheng (2011), "learning to learn is the ability to pursue and persist in learning, to manage one's own learning that includes effective management of time and information". Originally, self-regulated learning is referred to "an active, constructive process whereby learners set goals for their learning and then attempt to monitor, regulate, and control their cognition, motivation, and behavior, guided and constrained by their goals and the contextual features in the environment" (Pintrich, 2000). All these elements are known to influence the self-regulated learning or self-regulation of the learners in learning situation. It also can be said the self-regulated learning is the ways of learners itself take control of their own learning process. By having this process in their learning, it will help to inspire the student to learn and accomplish the task. Identification of students with high or poor in self-regulation learning also can be identified. Self-regulated learning can be embedded inside the student especially the student who is lacked or poor in self-regulated learning. However, this kind of learning also can be naturally inside the student who is highly self-regulation and seeking to be the best among his or her peers. 
According to Schunk (2005), most of the researchers today "apply self-regulatory principles to academic studying and other forms of learning, such as social and motor skills" (Boekaerts, Pintrich, \& Zeidner, 2000; Zimmerman \& Schunk, 2001). Self-regulated learning's research has been developed by many researchers especially in the area of educational psychology. Pintrich is an outstanding and well known researcher in this field of study. Pintrich has contributes many ideas and thought in his research regarding on self-regulated learning and this is why another researcher claimed he was a leading figure in the field of self-regulated learning (Schunk, 2005). From this, it can be said that self-regulated learning is a one educational legacy in educational psychology from Pintrich. Nevertheless, another researcher also have been together in contributed the ideas in the same field. This happen due to people does believe that self-regulated learning is essential in learner's everyday life (Ahmad Susanto, M. P., 2016).

According to Zimmerman (2001), the research presenting that learner's skill and abilities actually did not enough explain the student achievement. Then he suggested factors such as self-regulation and motivation were seen as a good mechanism in explain the student achievement and contribute to student improvement. In this study, researchers will be using two main factors in self-regulated learning such as motivation and learning strategies. Motivation consists of six sub-scales which are intrinsic and extrinsic goal, task value, control of learning beliefs, self-efficacy and test anxiety. For learning strategies consists of nine sub-scales for instance rehearsal, elaboration, organization, critical thinking, meta cognitive selfregulation, time management, effort regulation, peer learning and help seeking. So there will be 15 sub-3 scales that will be involved on in this study. Overall, these criteria will be scales in this study to see whether the self-regulated learning would give impacts or not to graduate student's academic performance in Universiti Malaysia Sarawak.

Nowadays, some of the students are lacked in self-regulation due to some factors. These impacts the student performance itself in educational or academic achievement. Meanwhile in order to produce an excellent student, high self-regulated learning must be existed inside the student in learning process. It is reasonable to state that student with high or good in self-regulated learning able to achieve good performance or vice versa. The ability of student in completing the task given also might be an influence from a student self-regulated learning. The researcher also highlights the problem statements and objectives as main referring in this research. This research also will be conduct among the graduate students in Faculty of Cognitive Sciences and Human Development, Universiti Malaysia Sarawak.

Nowadays, many graduate students in Universiti Malaysia Sarawak itself are not aware about the importance of self-regulated learning in their learning process like the student itself does not know what is self-regulated learning and how this learning actually can drive their motivates to learn. Actually, selfregulated has been an essential learning process or mechanism in students learning that contributes in student education such as getting a good achievement in academic and practical. Self-regulated learning involves the learners and their environment and this will influence the learner's achievement (Pintrich, 2000b; Pintrich \& Zusho, 2002). Besides, Pintrich also claimed that the learners also may simultaneously engage in some phases of self-regulated learning such as forethought, planning and activation, monitoring, control, reaction and reflection.

There is no doubt the role of educational psychology is arising and its plays an important mechanism or principles in today's education. In this century the task settlement and problem solving become more complex and challenging together with high development in education, management and in any field of learning. Every learner has to face the challenging task in order to survive and to accomplish the task given. The individual or student itself should apply the self-regulation inside themselves and to help them produce great outcomes in academic and practical learning. Plus, good in problem solving is one skill that student should have as one of their advantages or strength.

Sometimes, the students do not know what exactly motivates them to learn, able to complete the task or getting a good result either in academic achievement or in practical. They might get wrong in choosing the factors that can drive their motivation and sometimes underestimates with their own ability in learning. Poor self-regulation influences the student performance especially in education achievement. Student might get a bad result in examination, failed to accomplish the task given by lectures and unfortunately it can becomes worse when the student decides to drop out before the end of their study. Surely, this kind of situation should be taken before it becomes more worsen where student loss their motivation to learn this might give impacts to other students or peers. 
Other than that, learning strategies in self-regulated learning also might influence student academic performance. According to Ames and Archer (1988), learning strategies and learning goals usually depend on the orientation of the learning. Different kind of learning orientation will surely make the students used different learning strategies and this might affect with their academic performance. Wrongly use of learning strategies in self-regulated learning in students would give bad performance.

\section{Method}

The method or research design used in this research is a quantitative method by using formal instrument. All the data needed are derives from graduate students in FCSHD by distributes questionnaires to these students. Using this approach is suitable in order to get the statistic or numeric data from the students that will be used in data analysis. Population for this research are among graduate students in Faculty of Cognitive Science and Human development, Universiti Malaysia Sarawak. Eighty sample sizes of graduate students in were randomly selected for this study. The sampling method used is random sampling method. This research used a Motivated Strategies for Learning Questionnaire (MSLQ), developed by Pintrich and this questionnaire also is a legacy of Pintrich's work on self-regulation (Schunk, 2005). Both motivation and learning strategies' question will be answered in the MSLQ. The student as a respondent will rate themselves on a 7-point Likert scale, from 1(not at all true of me) until 7 (very true of me).

The data obtain from the research conduct were analyse by using the SPSS system. This system is used to acquire the result from the research that has been done by researcher. Other than that, this approach also is suitable in order to analyse the statically data obtained from students. This research used appropriate inferential data analysis in order to acquire the result which is Pearson correlation test. Pearson correlation is used to measure the strength direction of relationship between two random variables. By using Pearson correlation test in this research, it will have positive and negative correlation in result finding. Person correlation is denoted by $r$ that lies between -1 and $1,-1 \leq r \leq 1$.

\section{Results and Discussions}

Table 1 Correlation between Motivation and Academic Performance of the graduate students

\begin{tabular}{llcr}
\hline & & Motivation & CGPA \\
\hline Motivation & Pearson Correlation & 1 & .118 \\
& Sig. (2-tailed) & & .413 \\
\multirow{5}{*}{ CGPA } & $\mathrm{N}$ & 50 & 50 \\
& Pearson Correlation & .118 & 1 \\
& Sig. (2-tailed) & .413 & 50 \\
\hline
\end{tabular}

$\mathrm{H}_{\mathrm{o}} 1$ : There is no relationship of motivation among graduate students and their academic performance.

Table 1 shows that there is no relationship of motivation among graduate students and their academic performance. The $p$ value is more than .05 , so failed to reject the null hypothesis. This also means the variable of motivation does not affect the graduate students' academic performance. The $r$ value is .118. This eventually indicates the strength of the relationship is weak that lies between $.1<|r|<.3$.

Table 2 Correlation between Learning Strategies and Academic Performance of the graduate students

\begin{tabular}{llcr}
\hline & & Learning trategies & CGPA \\
\hline Learning & Pearson Correlation & 1 & .108 \\
Strategies & Sig. (2-tailed) & & .457 \\
& $\mathrm{~N}$ & 50 & 50 \\
CGPA & Pearson Correlation & .108 & 1 \\
& Sig. (2-tailed) & .457 & \\
& $\mathrm{~N}$ & 50 & 50 \\
\hline
\end{tabular}

$\mathrm{H}_{\mathrm{o}}$ 1: There is no relationship of learning strategies among graduate students and their academic performance. 
Table 2 shows that there is no relationship of learning strategies among graduate students and their academic performance. The $\mathrm{p}$ value is more than .05 , so failed to reject the null hypothesis. This also means the variable of learning strategies does not affect the graduate students' academic performance. The $\mathrm{r}$ value is .108. This eventually indicates the strength of the relationship is weak that lies between $.1<|\mathrm{r}|$ $<.3$. Both results above show that there is no relationship of motivation and learning strategies with academic performance. The dependent variable is a current CGPA of the graduate students. Table 2 and table 3 displays weak positive relationship where the both $\mathrm{r}$ value lies between $.1<|\mathrm{r}|<.3$ and the both $\mathrm{p}$ value is higher than 0.05 . Conclusion, the null hypothesis is accepted.

The results display there is no relationship of motivation and learning strategies among graduate students and their academic performance. Hsieh (2014) found that different student's background characteristics and learning motivation can expect diverse result. The different students background here means could be the student's level of education, cultures, knowledge, skills, experiences or others. Other than that, different student learning motivation also might influence the different result where it could be the students high or low level of motivation in learning. This implies that having motivation and learning strategies are not enough to lead the significance relationship towards their learning outcomes. Both results are not consistent with previous research (Korkmaz 2007; Redman 2010). However, Madoxx (2010) found that arrangement and motivation are correlated, yet he and others have not correlated these variables with academic performance by CGPA. So, it can be said that using graduate students current CGPA to be measure as learning outcomes in this research has led to new findings.

Based on the respond that was given, the items provided in questionnaire for this research is too many. This questionnaire consists of 81 items in which it is divided in two sections. Part 1 consist 31 items for motivation, while 50 items are in the part 2 for learning strategies. This could be the reason, some of the items were not fully answered by the respondents. In addition, there were 8 items in the questionnaire are reverse coded. All these items are needed to be taken carefully to avoid wrong interpretations or computation of the results. The items that are negatively expressed are items number $33,37,40,52,57,60$, 77 and 80. In order to avoid wrong data analysis, these items are firstly defines it values using the reverse coded function in the SPSS. For example, the likert scale used consists of 7 scales, if a respondents ticked scale 1 in negatively expressed item, the scored would be reverse and become 7 . By using this way, during key in the data scores, the system will automatically store the code that has been defined. Artino quoted from Pintrich et al. (1991) "the best way to calculate a reverse coded item is by deduct the original score from 8 ".

By involve other factors that may impacts the performance. Different characteristics of respondents background, predict different their learning outcomes. Thus, instead of using CGPA to measure learning results, another options can be consider to be used for future research for instance retention, satisfaction and graduation level. All these options can be evaluate to see if it leads to different results.

Another recommendation for future research is conduct a test with different student level of education. It can be focus on primary or secondary school students either in rural or in urban area. These might lead the researcher to new findings where the level competence of the primary and secondary school students might different with undergraduates and graduate level students. Other than that, by using other instrument and implementing different statistical analysis for data analysis might be consider to be used in the same research field. Instead of using MSLQ, there could be another similar instrument that can be used to measure the relationship between two variables with learning outcomes. Different statistical analysis also can direct the researcher to measure relationship between two variable more details and precise. The researcher can test on each aspect of each variable that involve in the research.

\section{Conclusions}

The findings provide evidence for the relation of motivation and learning strategies towards student's current CGPA which is consider being the student learning outcomes. Both variable display weak positive relationships in this research findings. Meaning, motivation and learning strategies are not sufficient enough to influence the graduate students' academic performance. That is why another factors need to consider to be used that might impacts graduate students learning outcomes. 


\section{References}

Ahmad Susanto, M. P. (2016). Teori belajar dan pembelajaran di sekolah dasar. Kencana.

American Psychological Association. (2009). Publication of manual of the American Psychological Association. Washington, DC: American Psychological Association.

Artino, R. A. (2005). A review of the motivated strategies for learning questionnaire. Retrieved from http://www.sp.uconn.edu.

Banarjee, P., \& Kumar, K. (2014). A study on self-regulated learning and academic achievement among the science graduates students. International Journal of Multidisciplinary Approach and Studies, 329-342.

Canter, M., Craciun, B. A. (2015, April). Forums used as tools for developing students' self- regulated learning skills in e-learning environment. Paper presented at the Eleventh International Scientific Conference eLearning and Software on Education Bucharest, Romania. Retrieved from http://eds.ebscohost.com/Legacy/Views/static/html.

Carneiro, R., Lefrere, P., Steffens, K., \& Underwood, J. (2011). Self-regulated learning in technology enhanced learning environments. Retrieved from http://www.sensepublishers.com/media.

Cassidy, S. (2011). Self-regulated learning in higher education: Identifying key component process. Studies in Higher Education, 36(8), 989-1000.

Coetzee, L. R. (2011). The relationship between students' academic self-concept, motivation and academic achievement at the university of the Free State. Retrieved from http://uir.unisa.ac.za/bitstream/handle/.

Duncan, T. G. (2005). The making of the motivated strategies for learning questionnaire. Educational Psychologist, 40(2), 117-128.

Ghamari, M. (2011). The relationship of internal motivation components and academic achievement among high schools students. International Journal of Human Resource Studies, 1(2), 89-97.Sajedi, R., \& Shafizadeh, H. (2015). A study relationship between learning strategies, achievement motivation and academic performance among the students of Semnan University of Medical Sciences in 2014-15. International Journal of Review in Life Sciences, 5(4), 268-276.

Hsieh, T. L. (2014). The relationship among different types of learning motivation, engagement behaviors and learning outcomes of undergraduates students in Taiwan. Science and Business Media, 64, 417-433.

Huang, S. C. (2008). Assessing motivation and learning strategies using the motivated strategies for learning questionnaire in a foreign language learning context. Social Behavior and Personality, 36(4), 529-534.

Kivinen, K. (2003). Assessing motivation and the use of learning strategies by secondary school students in three international schools (Academic dissertation, University of Tampere, Department of Education Finland). Retrieved from https://tampub.uta.fi/bitsream/handle.

Muhammad, A. S., Bakar, N. A., Mijinyawa, S. I., \& Halabi, K. A. (2015). Impact of motivation on students' academic performance: A case study of Universiti Sultan Zainal Abidin students. The American Journal of Innovative Research and Applied Sciences, 1(6), 221-226.

Onete, O. U. (2012). Academic performance: A function of achievement motivation among education students of Cross River University of Technology, Calabar. Retrieved from http://condor.lib.uoguelph.ca/index.php/rhea/article/viewFile/2185/2651.

Orhan, F. (2007). Applying self-regulated learning strategies in a blended learning Instruction. World Applied Science Journal, 2(4), 390-398.

Pintrich, P. R. (2004). A conceptual framework for assessing motivation and self-regulated learning in college students. Educational Psychology Review, 16(4), 385-407.

Pintrich, P. R., \& Groot, E. V. (1990). Motivational and self-regulated learning components of classroom academic performance. Journal of Educational Psychology, 82(1), 33-40.

Popa, D., \& Bazgan, M. (2014). A comparative analysis of some relevant conceptualizations of selfregulated learning. Journal Plus Education, 313-329.

Radovan, M. (2011). The relation between distance students' motivation, their use of learning strategies, and academic success. Journal of Educational Psychology, 10(1), 216-222.

Schunk, D. H. (2005). Self-regulated learning: The educational legacy of Paul R. Pintrich. Journal of Educational Psychology, 40(2), 85-94.

Sikhwari, T. D. (2014). A study relationship between motivation, self-concept and academic achievement of students at a University in Limpopo Province, South Africa. Retrieved from http://krepublishers.com/02-Journals/IJES/. 
Wolters, C. A., Pintrich, P. R., \& Karabenick, S. A. (2003, March). Assessing academic self- regulated learning. Paper presented at the Indicator of Positive Development Conference. Retrieved from www.childtrends.org/wp-content/uploads.

Zimmerman, B. J. (1990). Self-regulated learning and academic achievement. Educational Psychologist, 25(1), 3-17. 